\title{
The influence of temperature on cuticular color of honeybee (Apis mellifera $L$ ) queens
}

\author{
G DeGrandi-Hoffman 1, M Spivak 2, J Martin 1 \\ 1 Carl Hayden Bee Research Center, USDA - ARS, 2000 East Allen Road, Tucson, AZ 85719 \\ ${ }^{2}$ Center for Insect Science, University of Arizona, Tucson, AZ 85721, USA
}

(Received 18 May 1992; accepted 4 December 1992)

\begin{abstract}
Summary - Temperatures were monitored around emergency queen cells in queenless honeybee hives to determine the effect of temperature on queen color. Concurrently, sister queens of those reared in the queenless colony were placed in incubators set at $31.1,32.8$, or $34.4^{\circ} \mathrm{C}$ for the postcapping interval. Queens from the $34.4{ }^{\circ} \mathrm{C}$ incubator were significantly lighter in color than those in the $31.1^{\circ} \mathrm{C}$ in all but one trial. Queens that developed in the colony were not significantly different in color rank from those that emerged in the $34.4^{\circ} \mathrm{C}$ incubators in any trial, and from the 32.8 or $31.1^{\circ} \mathrm{C}$ incubators in most trials. The median color ranks of queens emerging in the colony did not differ throughout the year.
\end{abstract}

honeybee queen / temperature / cuticular color

\section{INTRODUCTION}

The influence of ambient temperature on the color of animals has been documented in a wide range of species (eg, Weatherby and Hart, 1984; Endo et al, 1985; Klein, 1988). In general, lighter morphs appear when ambient temperatures are high, and darker morphs when temperatures are low. A possible explanation for poikilotherms is that natural selection in warm climates favors a pale coat, skin, or shell to reflect sunlight and help the animal maintain a lower body temperature. In cool places a dark color is favored as it absorbs more energy and enables the ani- mal to reach its operating temperature more quickly and to maintain body temperature with less energy expenditure (Cowie, 1990).

Seasonal color morphs apparently occur in worker honeybees. This is surprising since honeybees are reared in the thermoregulated environment of a hive rather than under ambient temperature conditions (Milum, 1930; Lindauer, 1955; Free and Spencer-Booth, 1959; Simpson, 1961; Kronenberg and Heller, 1982). In workers of the Japanese honeybee (Apis cerana japonica) a yellow morph appears from July to October and a black morph from October to May (Okada, 1986). Con- 
stant temperature also influences cuticular color of queen honeybees (Apis mellifera) (Spivak et al, 1992). Queens are significantly darker when held at constant temperatures of $30.5^{\circ} \mathrm{C}$ during the last instar and pupal stages compared to $35.5^{\circ} \mathrm{C}$. Does temperature also influence cuticular color in colonies when broodnest temperatures fluctuate between $30-36{ }^{\circ} \mathrm{C}$ ? Are queens reared during cooler periods of the year darker than those reared during warmer months? The purpose of this study was to determine the influence of colony temperatures around queen cells on queen color throughout the year.

\section{MATERIALS AND METHODS}

This study was conducted at the Carl Hayden Bee Research Center in Tucson, Arizona from June 1990 to May 1991. Because of the climate in Tucson, honeybees rear brood and remain active year round. A single queen line from a closed population maintained at the center was used for the study (see Page and Laidlaw, 1985). Each queen was inseminated with an equal amount of pooled semen collected from 25 drones from each of 10 different queen lines. The queens had yellow and black striped abdomens and the drones used for the insemination ranged in color from yellow and black striped abdomens to completely black abdomens. With this mating scheme, a wide range of color patterns was possible in the offspring. Eight trials were conducted throughout the year with each trial being repeated twice per season. An 8frame queenless colony containing 10000 15000 honeybees and 4-5 frames of sealed and unsealed brood in standard Langstroth equipment was used in each trial. The queenless colony was checked for emergency queen cells $48 \mathrm{~h}$ after it was established.

At the time the queenless colony was established for each trial, larvae $<36 \mathrm{~h}$ old were transferred to queen cups to be reared into queens according to the procedure described in Laidlaw (1979). The larvae were from the same queenline and parent colony used to create the 8 -frame queenless colony. When the grafted queen cells were capped, equal numbers of them (10-20 cells/incubator depending upon the trial) were placed in incubators set at $31.1,32.8$ or $34.4^{\circ} \mathrm{C}$ (in all instances temperatures were \pm $0.30^{\circ} \mathrm{C}$ ). These temperatures were chosen because $34.4^{\circ} \mathrm{C}$ is the average temperature in the center of a colony's broodnest and $31.1^{\circ} \mathrm{C}$ is a temperature that occurs at the periphery (Milum, 1930). The third incubator set at $32.8^{\circ} \mathrm{C}$ served as a mid-range point. The capped queen cells were placed in individual glass vials in the incubators so that the queens could not escape when they emerged. In addition, a grafted queen cell was placed in the queenless colony next to each queen cell constructed by the workers (hereafter referred to as natural cells) $24 \mathrm{~h}$ after the larvae were grafted.

In the first spring trial the bees did not build queen cells around any worker larvae in the queenless colony, so grafted cells were placed on brood frames. In the other trials the bees constructed 6 or fewer natural cells, so the number of queen cells in the colony was supplemented by adding grafted cells next to each natural cell and by placing pairs of grafted cells in areas where there were no natural cells. Grafted cells were placed on frames with brood and on frames with only honey and pollen. When the queen cells in the colony were within $24 \mathrm{~h}$ of emerging, each was enclosed in a wire mesh cage to prevent the queen from escaping.

Temperature was monitored around queen cells in the colony using thermocouples connected to an automated micrologger (Omnidata International, Logan, UT). Thermocouples were placed next to each queen cell or between pairs of queen cells. Temperatures were monitored every $5 \mathrm{~min}$ and averaged and recorded each hour. Temperatures were recorded from the time that grafted cells were placed in the colony until all the queens emerged.

Queens emerging in the colony and in the incubators were placed in individual cages inside queenless colonies until they obtained their full pigmentation (at least $48 \mathrm{~h}$ after emergence). The queens were scored for color rank using the procedure described in Tsuruta et al (1989) and Spivak et al (1992). The color patterns of the third tergite (T3), fourth tergite (T4), fourth sternite (St4), and right hind leg (RHL) were used to determine the queen's color rank. The individual color scores of T3, T4, St4, RHL could range from $1-5$, and were summed to assign the 
queen's overall color rank. Color rankings ranged from 4-20 with higher scores indicating lighter colored queens.

\section{Data analysis}

Comparisons using a Kruskal-Wallis test were made among the median color ranks of queens that emerged in each incubator and those emerging in the colony (Ott, 1977). Separate tests were conducted for each trial. If the Kruskal-Wallis test indicated a rejection of the null hypothesis, individual Mann-Whitney tests were conducted comparing color ranks from each incubator with those from the colony (Jones, 1984). Comparisons across all the trials using a Kruskal-Wallis test were made among the median color ranks of queens emerging in the colony. Correlation coefficients of median color ranks for queens emerging in the colony and the average temperature around the cell from which each queen emerged were estimated using a Spearman's $\rho$ rank correlation test (Daniel, 1991).

\section{RESULTS}

Cells from which queens emerged had average temperatures between $32.2-34.7^{\circ} \mathrm{C}$ in the winter and spring, and $33.7-34.9^{\circ} \mathrm{C}$ in the summer and autumn (table I). In some instances queens exposed to similar temperature regimes had similar color ranks, but in other instances this was not the case. For example, during the winter trials when ambient temperatures were $<0^{\circ} \mathrm{C}$ and temperatures around queen cells were sometimes $<30^{\circ} \mathrm{C}$, color ranks ranged from 5 (an almost pure black queen) to 18 (a nearly pure yellow queen). In contrast, during the second summer trial, ambient temperatures reached $46{ }^{\circ} \mathrm{C}$ and temperatures around queen cells exceeded $39^{\circ} \mathrm{C}$ during some periods. In this trial both natural queens that emerged had color ranks of 20 .
The temperatures that the queen cells were exposed to in the incubators during the post-capping period provided a range of cuticular colors that could occur in the queens that emerged in the colony (table II). Median color ranks from the $34.4{ }^{\circ} \mathrm{C}$ incubators were significantly higher than those from the $31.1^{\circ} \mathrm{C}$ in all but the first winter trial. There was no significant difference between the median color ranks of queen emerging in the colony and in the $34.4{ }^{\circ} \mathrm{C}$ incubator in any of the trials. A separate Kruskal-Wallis test that included only those queens emerging in the colony indicated that there was no significant difference in median color ranks among the queens regardless of the time of year when the trial was conducted $(H=9.09$, $k=7, \chi^{2}$ for rejection of $H_{0}=14.07$ ).

The correlation coefficient of median color rank and average temperature was 0.358 ( $\rho \leq 0.05$ ) (table III). The color rank of the RHL had the highest correlation coefficient and St 4 the lowest.

\section{DISCUSSION}

Under the fluctuating temperature conditions in the hive, the average temperature around a queen cell did not greatly influence the color of queens. However, the colors of the body parts scored in this study were not independent of temperature, except for the 4th sternite. Median color scores of queens emerging in colonies did not differ significantly throughout the year. As in a previous study (Spivak et al, 1992), the color of the RHL was most affected by temperature.

The inheritance of abdomen color in honeybees is controlled by genes on at least 7 different loci (Roberts and Mackensen, 1951). There is also an inhibitor gene that when homozygous prevents the development of yellow body color in worker 
Table I. Average hourly temperatures and temperature ranges around emergency queen cells in a honeybee colony. An 8-frame queenless colony was used for each trial. The number of the thermocouple monitoring the temperatures around each pair of queen cells or a single queen cell is indicated by TC-1 (ie thermocouple 1) through TC-6. The color rank of the emerging queens is included.

\begin{tabular}{|c|c|c|c|c|c|c|c|}
\hline \multirow[t]{2}{*}{$\begin{array}{l}\text { Trial No } \\
\text { and } \\
\text { season }\end{array}$} & \multicolumn{6}{|c|}{$\begin{array}{c}\text { Average temperature }\left({ }^{\circ} \mathrm{C}\right) \\
\text { Temperature range around each queen cell } \\
\text { Color rank of emerging queen }{ }^{*}\end{array}$} & \multirow{2}{*}{$\begin{array}{c}\text { Average } \\
\text { temperature } \\
\left({ }^{\circ} \mathrm{C}\right) \\
\text { temperature } \\
\text { range }\end{array}$} \\
\hline & $T C-1$ & $T C-2$ & $T C-3$ & $T C-4$ & $T C-5$ & $T C-6$ & \\
\hline $\begin{array}{l}\text { Ist } \\
\text { spring }\end{array}$ & $\begin{array}{c}32.9 \\
30.5-34.5 \\
14,17\end{array}$ & $\begin{array}{l}\text { NA } \\
\text { NA }\end{array}$ & $\begin{array}{c}33.2 \\
31.4-34.6 \\
9,18\end{array}$ & $\begin{array}{c}34.8^{* *} \\
33.6-35.7\end{array}$ & $\begin{array}{c}33.7 \\
31.9-35.2 \\
16, \text { dead }\end{array}$ & $\begin{array}{c}28 . d \\
15.1-33.8 \\
\text { Both dead }\end{array}$ & $\begin{array}{c}14.4 \\
0.5-25.8\end{array}$ \\
\hline $\begin{array}{l}\text { 2nd } \\
\text { spring }\end{array}$ & $\begin{array}{c}33.7 \\
30.9-36.3 \\
17,16\end{array}$ & $\begin{array}{l}\text { NA } \\
\text { NA }\end{array}$ & $\begin{array}{c}34.7 \\
33.5-36.5 \\
17,17\end{array}$ & $\begin{array}{c}34.6 \\
32.6-36.4 \\
\text { Both dead }\end{array}$ & $\begin{array}{l}34.7 \\
32.3-38.5 \\
17, \text { dead }\end{array}$ & $\begin{array}{c}32.9 \\
26.4-35.8 \\
\text { Both dead }\end{array}$ & $\begin{array}{c}18.4 \\
3.0-33.3\end{array}$ \\
\hline $\begin{array}{l}\text { 1st } \\
\text { summer }\end{array}$ & $\begin{array}{c}34.4 \\
31.6-36.2 \\
15,20\end{array}$ & $\begin{array}{c}34.7 \\
30.5-37.6 \\
19, \text { dead }\end{array}$ & $\begin{array}{l}\text { NA } \\
\text { NA }\end{array}$ & $\begin{array}{l}\text { NA } \\
\text { NA }\end{array}$ & $\begin{array}{c}34.1 \\
31.5-36.5 \\
16,13\end{array}$ & $\begin{array}{c}34.5 \\
33.3-36.5 \\
9,13\end{array}$ & $\begin{array}{c}23.8 \\
10.2-36.7\end{array}$ \\
\hline $\begin{array}{l}\text { 2nd } \\
\text { summer }\end{array}$ & $\begin{array}{c}35.4 \\
33.5-40.1 \\
\text { Dead }\end{array}$ & $\begin{array}{c}34.9 \\
25.6-41.2 \\
20\end{array}$ & $\begin{array}{l}35.4 \\
29.5-41.6 \\
\text { Dead }\end{array}$ & $\begin{array}{l}35.0 \\
33.9-36.2 \\
\text { Dead }\end{array}$ & $\begin{array}{l}34.7 \\
30.9-39.4 \\
20\end{array}$ & $\begin{array}{l}35.3 \\
33.9-36.5 \\
\text { Dead }\end{array}$ & $\begin{array}{c}35.8 \\
20.8-46.4\end{array}$ \\
\hline $\begin{array}{l}\text { 1st } \\
\text { autumn }\end{array}$ & $\begin{array}{c}33.7 \\
31.7-35.8 \\
19,15\end{array}$ & $\begin{array}{l}34.3 \\
31.3-36.0 \\
11, \text { dead }\end{array}$ & $\begin{array}{l}34.6 \\
32.5-36.1 \\
14,16\end{array}$ & $\begin{array}{c}33.6 \\
31.0-35.5 \\
15 \text {,dead }\end{array}$ & $\begin{array}{c}34.5 \\
31.1-36.0 \\
18 \text {,dead }\end{array}$ & $\begin{array}{c}32.1 \\
27.5-34.9 \\
\text { Both dead }\end{array}$ & $\begin{array}{c}20.8 \\
5.7-34.0\end{array}$ \\
\hline $\begin{array}{l}\text { 2nd } \\
\text { autumn }\end{array}$ & $\begin{array}{c}33.7 \\
31.1-35.4 \\
13, \text { dead }\end{array}$ & $\begin{array}{c}34.4 \\
32.1-35.7 \\
14,15\end{array}$ & $\begin{array}{c}34.4 \\
32.4-35.5 \\
20 \text {,dead }\end{array}$ & $\begin{array}{c}33.8 \\
31.1-36.9 \\
10,20\end{array}$ & $\begin{array}{c}33.0 \\
30.1-34.9 \\
10,19\end{array}$ & $\begin{array}{c}27.7 \\
18.2-33.9 \\
\text { Both dead }\end{array}$ & $\begin{array}{c}15.1 \\
3.3-31.1\end{array}$ \\
\hline $\begin{array}{l}\text { tst } \\
\text { winter }\end{array}$ & $\begin{array}{c}32.3 \\
28.8-34.7 \\
12,12\end{array}$ & $\begin{array}{c}32.9 \\
31.0-35.6 \\
12,17\end{array}$ & $\begin{array}{c}33.2 \\
30.8-35.1 \\
8,17\end{array}$ & $\begin{array}{c}31.9 \\
23.9-34.9 \\
\text { Both dead }\end{array}$ & $\begin{array}{c}32.7 \\
30.1-35.2 \\
14, \text { dead }\end{array}$ & $\begin{array}{c}32.6 \\
29.1-35.9 \\
15 \text {,dead }\end{array}$ & $\begin{array}{c}11.6 \\
-1.6-25.5\end{array}$ \\
\hline $\begin{array}{l}\text { 2nd } \\
\text { winter }\end{array}$ & $\begin{array}{c}30.2 \\
20.2-34.0 \\
\text { Both dead }\end{array}$ & $\begin{array}{c}32.4 \\
29.7-35.7 \\
18, \text { dead }\end{array}$ & $\begin{array}{c}34.4^{*} \\
31.9-35.3\end{array}$ & $\begin{array}{c}33.1 \\
28.8-35.0 \\
5,9\end{array}$ & $\begin{array}{c}32.7 \\
25.1-35.1 \\
15,14\end{array}$ & $\begin{array}{c}27.6 \\
18.5-34.4 \\
\text { Both dead }\end{array}$ & $\begin{array}{c}8.8 \\
0.5-20.1\end{array}$ \\
\hline
\end{tabular}

" Queen color ranks were assigned according to a procedure described in Spivak et al (1992); "* temperature probe located in the center of the broodnest where there was no queen cell.

bees, and when hemizygous prevents the production of yellow males (Laidlaw and El-Banby, 1962). This study and that of Spivak et al (1992) demonstrated that the expression of genes for color is modulated by constant temperatures. Queens were inseminated with drones from many queens in our study, while in the previous 
Table II. The median color score for queens whose cells were placed in incubators during their postcapping period and for those reared in colonies and emerging there.

\begin{tabular}{|c|c|c|c|c|}
\hline \multirow[t]{3}{*}{ Trial } & \multicolumn{4}{|c|}{$\begin{array}{l}\text { Median color score * } \\
\text { Range of color scores } \\
(\mathrm{n})^{\star *}\end{array}$} \\
\hline & \multicolumn{3}{|c|}{ Incubator temperatures $\left({ }^{\circ} \mathrm{C}\right)$} & \multirow[t]{2}{*}{ Colony } \\
\hline & $34.4^{\circ}$ & $32.8^{\circ}$ & $31.1^{\circ}$ & \\
\hline \multirow[t]{3}{*}{ 1st spring } & $16.0^{\mathrm{a}}$ & $13.0^{\mathrm{b}}$ & $13.0^{\mathrm{b}}$ & $16.0^{a b}$ \\
\hline & 5-19 & $9-17$ & $8-15$ & $9-18$ \\
\hline & $(15)$ & $(13)$ & $(15)$ & (7) \\
\hline \multirow[t]{3}{*}{ 2nd spring } & $15.0^{a b}$ & $13.0^{b c}$ & $14.0^{\circ} \mathrm{c}$ & $17.0^{a}$ \\
\hline & $11-18$ & $8-16$ & $8-15$ & $16-17$ \\
\hline & (13) & (12) & (12) & (6) \\
\hline \multirow[t]{3}{*}{ 1st summer } & $17.5^{\mathrm{a}}$ & 14.0 ab & $11.0^{\mathrm{b}}$ & $15.0^{a}$ \\
\hline & $11-20$ & $6-18$ & $6-17$ & $9-20$ \\
\hline & $(10)$ & (9) & (11) & (10) \\
\hline 2nd summer & NA & NA & NA & $\begin{array}{c}20.0 \\
\text { (2) }\end{array}$ \\
\hline \multirow[t]{3}{*}{ 1st autumn } & $18.0^{\mathrm{a}}$ & $14.0^{\mathrm{b}}$ & $13.0^{b}$ & 15.0 ab \\
\hline & $13-20$ & $10-18$ & $10-18$ & $11-19$ \\
\hline & (10) & (10) & (8) & (7) \\
\hline \multirow[t]{3}{*}{ 2nd autumn } & $15.0^{\mathrm{a}}$ & $11.0 \mathrm{bc}$ & $11.0 \mathrm{c}$ & $14.5 \mathrm{ab}$ \\
\hline & $10-20$ & $6-17$ & $4-17$ & $10-20$ \\
\hline & $(17)$ & (13) & $(16)$ & (8) \\
\hline \multirow[t]{3}{*}{ 1st winter } & $15.0^{\mathrm{a}}$ & $13.5^{\mathrm{a}}$ & $13.0^{\mathrm{a}}$ & $13.0^{\mathrm{a}}$ \\
\hline & $11-20$ & $12-17$ & $8-19$ & $8-17$ \\
\hline & $(14)$ & $(14)$ & $(12)$ & (8) \\
\hline \multirow[t]{3}{*}{ 2nd winter } & $15.0^{\prime} \mathrm{a}$ & $16.0^{\mathrm{a}}$ & $11.0^{b}$ & $14.0^{\mathrm{ab}}$ \\
\hline & $7-20$ & $8-18$ & $4-15$ & 5-18 \\
\hline & $(16)$ & (19) & (15) & (5) \\
\hline
\end{tabular}

* Differences among median color scores for each trial were determined using a Kruskal-Wallis test. If this test indicated a rejection of the null hypothesis, individual Mann-Whitney tests between median scores within a trial were conducted at the 0.05 level. Median scores followed by the same letter within each trial are not significantly different. "* No of queen scored.

study queens were inseminated with drones from a single queen source. There was a much greater degree of phenotypic variability in the offspring of our queens compared to those inseminated with a single patriline. However, differences in the median color ranks of queens emerging in the incubators still occurred, particularly between those exposed to constant temperatures of 34.4 and $31.1{ }^{\circ} \mathrm{C}$ during the post-capping interval.

Differences in queen color due to temperature as observed in the incubators were not observed in queens emerging in 
Table III. Correlation coefficients of median color scores from 47 queens and average temperature around the cells from which those queens emerged.

Character
$\begin{gathered}\text { Rank correlation } \\ \text { coefficients }\end{gathered}$

\begin{tabular}{lll} 
3rd tergite & 0.314 & $\leq 0.05$ \\
4th tergite & 0.341 & $\leq 0.05$ \\
4th sternite & 0.206 & $\geq 0.05$ \\
Right hind leg & 0.435 & $\leq 0.05$ \\
Total color score & 0.358 & $\leq 0.05$ \\
\hline
\end{tabular}

* Rank correlation coefficients determined using Spearman's $\rho$ rank correlation test.

the colony. Queens are reared under fluctuating temperatures in the hive which seems to obscure the effect of temperature on color unless extreme conditions occur. It is possible though, that if the phenotypic variability had been reduced by inseminating queens with one drone or a single patriline, the effect of temperature on queen color in the colony might have been more dramatic.

\section{ACKNOWLEDGMENTS}

The authors thank E Erickson Jr, J Hagler, H Laidlaw, and $W$ Wcislo for their valuable comments during the preparation of this manuscript, and to the Center for Insect Science at the University of Arizona for partial funding of this research.

Résumé - Influence de la température sur la couleur de la cuticule des reines d'abeille (Apis mellifera L). La température dans la colonie autour des cellules royales a été enregistrée durant tout le dé- veloppement de la reine, afin de déterminer son effet sur la couleur de la cuticule des reines. En outre, des cellules de reines greffées ont été mises dans des étuves à température constante $(34,4,32,8$ et $31,1^{\circ} \mathrm{C}$ ) pour déterminer si une température constante exerçait une influence sur la couleur de la cuticule. Dans tous les cas, les reines descendaient d'une même reine qui avait été inséminée avec un mélange de spermes issus de 10 lignées maternelles différentes. L'étude a été faite sur une année, avec 2 répétitions à chaque saison. On a utilisé pour chaque expérience une colonie orpheline de 10000 à 15000 abeilles sur 8 cadres et 4 à 5 rayons de couvain operculé et non operculé. La note de couleur attribuée à chaque reine a été déterminée d'après la couleur des $3 e$ et $4 \mathrm{e}$ tergites, du $4^{\mathrm{e}}$ sternite et de la patte postérieure droite (Tsuruta et al, 1989; Spivak et al, 1992). Les notes ont varié entre 4 et 20 , les notes les plus hautes correspondant aux reines les plus claires. Les cellules d'où émergeaient les reines dans la colonie avaient des températures moyennes comprises entre 32,2 et $34,7^{\circ} \mathrm{C}$ en hiver et au printemps et entre 33,7 et $34,9^{\circ} \mathrm{C}$ en été et à l'automne (tableau I). Les reines qui avaient été exposées aux mêmes conditions de température dans la colonie et en étuve n'ont pas eu nécessairement la même couleur de cuticule. Les valeurs médianes de la couleur des reines naissant en étuve à $34,4^{\circ} \mathrm{C}$ ont toujours été plus élevées que celles des reines naissant en étuve à $31,1^{\circ} \mathrm{C}$, sauf au cours du premier essai hivernal (tableau II). Les notes de couleur attribuées aux reines nées dans la colonie n'ont pas varié au cours de l'année. Le coefficient de corrélation de la valeur médiane de la couleur et de la température moyenne a été de 0,358 pour les reines nées dans la colonie. La note de couleur de la patte postérieure droite a été la plus fortement corrélée avec la tempéra- 
ture et celle du $4^{\mathrm{e}}$ sternite la plus faiblement. Le fait que les températures auxquelles les reines sont élevées dans la colonie fluctuent, semble masquer l'influence de la température sur la couleur de la cuticule, qui existe en étuve. En raison du schéma d'accouplement choisi dans cette expérimentation, un fort degré de variabilité phénotypique dans la descendance de la reine était possible. L'influence de la température sur la couleur des reines nées dans la colonie aurait été peut-être plus marquée si les reines avaient été inséminées avec un seul mâle ou avec des mâles d'une même lignée paternelle.

reine / couleur de la cuticule / température

\section{Zusammenfassung - Der Einfluß der} Temperatur auf die Körperfarbe der Bienenkönigin. Die Temperatur rund um Weiselzellen wurde während der gesamten Entwicklungszeit überwacht, um deren Einfluß auf die Farbe der Cuticula der Königin zu bestimmen. Zusätzlich wurden noch Weiselzellen, gewonnen nach dem Umlarvverfahren, nach der Verdeckelung im Brutschrank bei verschiedenen, konstanten Temperaturen gehalten $\left(34,4{ }^{\circ} \mathrm{C}\right.$, $32,8^{\circ} \mathrm{C}$ und $31,1^{\circ} \mathrm{C}$ ), um den Einfluß konstanter Temperaturen auf die Farbe der Königin zu bestimmen. In allen Fällen waren die Königinnen Nachkommen einer einzigen Königin, die mit dem gemischten Samen aus 10 verschiedenen KöniginnenLinien besamt worden war.

Die Untersuchung wurde das ganze Jahr über durchgeführt, wobei auf jede Saison zwei Versuche fielen. Für jeden Versuch wurden weisellose Völker zu 8 Rähmchen mit 10 000-15 000 Bienen und 4-5 Rähmchen mit verdeckelter und unverdeckelter Brut verwendet. Es wurden die Farbe des dritten und vierten Tergites, des vierten Sternites und des Hinterbeines zur Bestimmung der Farbklasse jeder Königin benutzt (Tsuruta et al, 1989; Spivak et al, 1992). Die Farbklassen der Königinnen schwankten zwischen 4-20, wobei höhere Farbklassen hellere Färbungen der Königinnen bedeuteten.

Die Zellen, aus denen die Königinnen in den Völkern schlüpften, wiesen im Winter und Frühjahr mittlere Temperaturen zwischen $32,2^{\circ}-34,7^{\circ} \mathrm{C}$ auf, und $33,7^{\circ}$ $34,9^{\circ} \mathrm{C}$ im Sommer und Herbst (Tabelle I). Königinnen, die im Volk und im Brutschrank ähnlichen Temperaturen ausgesetzt waren, hatten nicht notwendigerweise ähnliche Farbmuster der Körperoberfläche. Die mittleren Farbklassen von Königinnen, die bei $34,4^{\circ} \mathrm{C}$ im Brutschrank geschlüpft waren, lagen immer höher als diejenigen von Königinnen aus dem Brutschrank bei $31,1^{\circ} \mathrm{C}$, ausgenommen derjenigen aus dem ersten Winterversuch (Tabelle II). Die Farbwerte der im Volk geschlüpften Königinnen änderten sich das Jahr über nicht. Der Korrelationskoeffizient zwischen mittlerem Farbwert und der durchschnittlichen Temperatur betrug für die im Volk geschlüpften Königinnen 0,358 . Der Farbwert des rechten Hinterbeins zeigte die höchste Korrelation mit der Temperatur, und das vierte Sternit die niedrigste.

Die schwankenden Temperaturen, unter denen die Königinnen im Volk aufgezogen werden, schienen den Einfluß der Temperatur auf die Körperfarbe zu verschleiern, der im Brutschrank vorhanden war. Infolge des in diesem Experiment benutzten Paarungsschemas bestand zu einem hohen Grad die Möglichkeit einer phänotypischer Variabilität in der Nachkommenschaft unserer Königinnen. Es ist möglich, daß der Einfluß der Temperatur auf die Farbe der im Volk geschlüpften Königinnen deutlicher hervorgetreten wäre, wenn die Königinnen nur mit einem einzigen Drohn oder 
mit Drohnen aus einer einzigen väterlichen Linie besamt worden wären.

\section{Honigbiene / Königin / Temperatur / Farbe der Cuticula}

\section{REFERENCES}

Cowie RH (1990) Climatic selection on body colour in the land snail Theba pisana (Pulmonata: Helicidae). Heredity 65, 123-126

Daniel WW (1991) Biostatistics: a Foundation for Analysis in the Health Sciences. John Wiley and Sons, New York, NY

Endo K, Maruyama Y, Sasaki K (1985) Environmental factors controlling seasonal morph determination in the small copper butterfly, Lycaena phlaeas daimio Seitz. I Insect Physio/ 31, 525-532

Free JB, Spencer-Booth $Y$ (1959) Temperature regulation by honeybees. Bee World 40, 173-177

Jones D (1984) The use, misuse, and role of multiple-comparison procedures in ecological and agricultural entomology. Environ Entomol 13, 635-649

Klein $M$ (1988) Color morphs induced under controlled environmental conditions in adult Earias insulana (Lepidoptera: Noctuidae). Environ Entomol 17, 162-165

Kronenberg F, Heller HC (1982) Colonial thermoregulation in honey bees (Apis mellifera L). J Comp Physiol 148, 65-76

Laidlaw HH Jr (1979) Contemporary Queen Rearing. Dadant and Sons Inc, Hamilton, IL
Laidlaw $\mathrm{HH}$, el-Banby MA (1962) Inhibition of yellow body color in the honey bee. $J$ Hered 53, 171-173

Lindauer M (1955) The water economy and temperature regulation of the honeybee colony. Bee World 36, 62-72, 81-92, 105-111

Milum VG (1930) Variations in the time development of the honey bee. $J$ Econ Entomol 23, 441-446

Okada I (1986) Biological characteristics of the Japanese honey bee, Apis cerana japonica. In: Proc 30th Int Apic Congr. Apimondia, 119122

Ott $L$ (1977) An Introduction to Statistical Methods and Data Analysis. Duxbury Press, North Scituate, MA

Page RE Jr, Laidlaw HH Jr (1985) Closed population honeybee breeding. Bee World 66, 6372

Roberts WC, Mackensen O (1951) Breeding improved honey bees. II. Heredity and variation. Am Bee J 91, 328-330

Simpson J (1961) Nest climate regulation in honey bee colonies. Science 133, 1327-1333

Spivak M, Zeltzer A, DeGrandi-Hoffman G, Martin $J$ (1992) The influence of temperature on the rate of development and color patterns of queen honey bees (Apis mellifera $\mathrm{L}$ ). Environ Entomol 21 (2), 364-370

Tsuruta TM, Matsuka M, Sasaki M (1989) Temperature as a causative factor in the seasonal colour dimorphism of Apis cerana japonica workers. Apidologie 20, 149-155

Weatherby JC, Hart ER (1984) Seasonal development and color morph determination of the yellowheaded fireworm (Lepidoptera: Tortricidae). Environ Entomol 13, 818-821 